\title{
Impact of climate change on yield of different crops grown in Cachar district of Assam, India
}

\author{
Diplina Paul, Laxmi N. Sethi ${ }^{*}$, Bhaskar J. Deka, Sudipto Sarkar and Avinash Kumar
}

Department of Agricultural Engineering, Assam University, Silchar-788011 (Assam), INDIA

*Corresponding author's E-mail: Insethi06@gmail.com

\section{ARTICLE HISTORY}

Received: 14 November 2017

Revised received: 20 November 2017

Accepted: 26 November 2017

Keywords

Agriculture

Cachar

Climate change

Correlation

Crop yield

Growing seasons

Statistical analysis

\begin{abstract}
Impact of climate change on crop yield threatens food security which is detrimental to agricultural sector. Cachar district of Assam is a climate susceptible district due to its unique geographical location and hydrological regime in north-eastern India. So, the present study was carried out to assess impact of climate change on crop yield for sustainability of agriculture. Climatic data viz., rainfall, maximum-minimum temperature and sunshine hours were collected from an observatory of Tea Research Association, Silcoorie, Cachar district for 2007-2012. Statistical and correlation analysis was employed to evaluate potential climate change impact on productivity of twenty three major crops of the study site. The correlation coefficient ( $r$, Pearson's Product Moment) between any climatic parameter and crop yield implied that climate has strong linear correlation with yield of crops resulting in twenty-two strong correlations. Among the climatic parameters rainfall was found to have most significant impact on yield. Noteworthy reduction was observed in yield of Autumn Paddy and Winter Paddy by 8.75 and 20.44 during the year $2008-2009$ due to 3.98 and $36.22 \%$ decrease of rainfall with $r$ values 0.95 and -0.76 , respectively. Also, a quantum leap of $145.32 \%$ increase of rainfall during Rabi season of 2007-2008 decreased the yield of Potato and Rabi vegetables by 22.96 and $16.89 \%$, respectively. The study revealed that climate change has significant impact on crop yield which could be alleviated by adopting rainwater harvesting technology at the top and foot hills of the hilly areas.
\end{abstract}

C2017 Agriculture and Environmental Science Academy

Citation of this article: Paul, D., Sethi, L.N., Deka, B.J., Sarkar, S. and Kumar, A. (2017). Impact of climate change on yield of different crops grown in Cachar district of Assam, India. Archives of Agriculture and Environmental Science, 2(4): 330-335, DOI: $10.26832 / 24566632.2017 .020415$

\section{INTRODUCTION}

Global climate change induced by increasing concentrations of greenhouse gasses in the atmosphere is likely to increase temperatures, change precipitation patterns and increase the frequency of extreme events. Climate change refers to all forms of climatic inconsistency regardless of their statistical nature (Mitchell et al., 1966). It may be conveyed as changes in the climate over time whether due to the natural variability or a result of human induced activities (IPCC, 2007). Anthropogenic greenhouse gas emissions as a result of industrialization and urbanization have made significant contributions to global warming and further changes in the global climate (Kumar and Chopra, 2009; Gohari et al., 2013). As a result, global temperature rose by $0.74^{\circ} \mathrm{C}$ ranging from 0.56 to $0.92^{\circ} \mathrm{C}$ during the tenure 1906 to 2005 . By the end of $21^{\text {st }}$ century, the global air surface temperature will continue to increase by 1.8 to $4^{\circ} \mathrm{C}$ (IPCC, 2007). Global warming also causes changes in precipitation levels and patterns due to higher evapotran spiration and water vapour amounts in the atmosphere with several implications for the global hydrological cycle. Through the impacts on agro-climatological parameters, concomitantly crop yield is also affected, thus jeopardizing food security.
As agriculture is one of the most vulnerable sectors susceptible to climate change and also the major water consumer of the developing world and some developed countries. Olarenwaju (2012) had declared that many of the problems facing agricultural sector are climate related. It can be concluded that climate parameters are the major environmental factors capable of affecting agriculture. Kumar et al. (2015) concluded in their study that scientists concurred with the fact that climate changes ushered in additional stress on the already fragile systems of agriculture as well as affected crop physiology. Changes in temperature and precipitation may either benefit or harm agricultural systems depending on the location in the world (Chavas et al., 2009, Ruane et al., 2013, Mishra et al., 2013). Climatic parameters such as solar radiation, temperature, moisture, rainfall etc. determine the global distribution of crops and livestock as well as crop yield and livestock productivity (Ajadi et al., 2011). Agricultural crop production might be significantly affected by changes in climate and rising $\mathrm{CO}_{2}$ levels. The increased $\mathrm{CO}_{2}$ levels enhance photosynthesis rates (i.e. $\mathrm{CO}_{2}$ enrichment effect), yields in some and water use efficiency (WUE) under water stress conditions. Therefore, the overall effect of increased $\mathrm{CO}_{2}$ levels and climate change on crop yields will depend on local climatic conditions as well 
as cropping systems and practices like biomass burning, crop residue removal (Manna et al., 2015). To ensure sustainability of agriculture, studying the possible climate change impacts on this sector is essential. Thus, the present study was undertaken to ascertain the impact of climate on agriculture in Cachar district, Assam.

\section{MATERIALS AND METHODS}

Study area: Based on the availability of climatic and crop parameters data, Cachar district of Assam, India was selected as study area for the present study. Cachar district, situated in the southern part of Assam of India is surrounded by hills on three sides with a geographical area of $3786 \mathrm{~km}^{2}$ (Figure 1). Its longitude extends from $92^{\circ} 24^{\prime}$ to $93^{\circ} 15^{\prime} \mathrm{E}$ and latitude from $24^{\circ} 22^{\prime}$ to $25^{\circ} 8^{\prime} \mathrm{N}$. The altitude of the highest point is $36.5 \mathrm{~m}$ from MSL. The soil is mainly acidic in reaction, with $\mathrm{pH}$ range 4.5-5.9.

The southern part of Assam enjoys a hot and humid climate with high relative humidity. The maximum temperature ranges from $35-37^{\circ} \mathrm{C}$ and minimum temperature from $9-11^{\circ} \mathrm{C}$. The maximum relative humidity observed during summer is 90 $95 \%$ and the lowest observed during winter is $65-70 \%$. Apart from the extreme humidity the most distinguishing feature of climate of this region is a high rainfall belt with copious average annual rainfall of $2800 \mathrm{~mm}$. The area is characterized by tropical monsoon climate having two distinct agricultural seasons viz. rainy/Kharif (April-September) and winter/Rabi (October-March) and three seasons for the staple crop of this region, Paddy viz. Ahu/autumn (February-July), Sali/summer (June-December) and Boro/winter (November-June). Presently less than $2 \%$ of the total cropped area is under irrigation and rest $98 \%$ of the total cropped area is rain-fed (Anonymous, 2012-2013).

Cropping pattern and crop yield: Wide variation of physiographic features and climatic characteristics have resulted in three distinct growing seasons of rice (Oryza sativa) which is grown in plenty: Ahu or Autumn, Sali or Winter and Boro or Summer. Apart from paddy, various other cereals, pulses, oil seeds, fibers and vegetables are grown in this region. In the present study, twenty three crops were considered to study the impact of climate change on their yield. The various crops along with their cropping pattern that have been considered in this study have been summarized in Table 1. The yields of various crops were sourced from the Status Paper of Cachar district for the period available viz. 2007-2010 and 2011-2012 published by the Department of Agriculture, Cachar district, Silchar on an annual basis.

Assessment of climate variability: The climate variability of the study area was assessed for the climatic parameters like rainfall, maximum and minimum temperature and sunshine hours recorded per day observed in the study site. The observed data were collected from the Tea Research Association (TRA) observatory, Silcoorie, Cachar district. The data of daily rainfall, daily maximum and minimum temperature and sunshine hours recorded per day were collected for the duration 2007-2012 to analyze the impact of climate change on the crop yield during the years under purview.

Analysis of agriculture-climate relationship: Various methods have been reported for establishing agriculture-climate relationship (Ajadi et al., 2011). One endeavour is to establish fundamentals of plant-climate relationship in the terms of moisture balance of various crops in different climatic conditions and solar radiation (Olaniran, 1981). The other method involves analysing the crop yield for a particular area for a particular period of time (as much constant record of agricultural crop yield data and climatic data would permit) and arrive at an agro-climatological relationship. The latter method was employed in the present study: correlation was used in showing the relationship between climatic parameters and crop yield, the trend and variation in crop yield over the years 2007-2012 (duration for which the data of crop yield was available) in the study area. These statistical techniques were employed in the analysis of both crop yield data and climatic parameters because of their vital roles in revealing the relationship and variation among variables.

The mean value was calculated by using Arithmetic Mean Method. If $X_{1}, X_{2}, X_{3} \ldots X_{N}$ are the measured values of day 1, 2, $3 \ldots N$, then their mean value $(\overline{\mathrm{x}})$ is given by:

$$
\bar{X}=\frac{x_{1}+x_{\mathrm{n}}+x_{\mathrm{g}}+\ldots+x_{\mathrm{N}}}{N}
$$

The standard deviation, $(\sigma)$ was estimated using the following equation:

$$
\sigma=\sqrt{\frac{N\left[\bar{R}^{2}-(x)^{2}\right]}{N-1}}
$$

Coefficient of variation $\left(C_{v}\right)$ compares the degree of variation from one data series to another, even if the means are drastically different from each other. It shows the extent of variability in relation to mean of the population. It is computed as under:

$$
\text { Coefficient of Variation }=\frac{\sigma}{x} \times 100
$$

Correlation shows whether and how strongly pairs of variables are related. The numerical measure of correlation is called the coefficient of correlation $(r)$. The correlation (Pearson's Product Moment) between any two parameters $X$ and $Y$ can be expressed as:

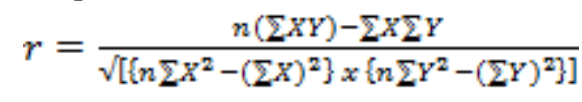

Where $\mathrm{n}=$ total number of observations on $X$ and $Y$ and $-1 \leq r$ $\geq 1$. The interpretation of values of $r$ is:

Here, 0 indicates no linear relationship; +1 indicates a perfect positive linear relationship: as one variable increases in its values, the other variable also increases in its values; -1 indicates a perfect negative linear relationship: as one variable increases in its values, the other variable decreases in its values; Values between 0 and 0.3 ( 0 and -0.3$)$ indicate a weak positive (negative) linear relationship; Values between 0.3 and 0.7 (0.3 and -0.7) indicate a moderate positive (negative) linear relationship; Values between 0.7 and 1.0 (-0.7 and -1.0) indicate a strong positive (negative) linear relationship.

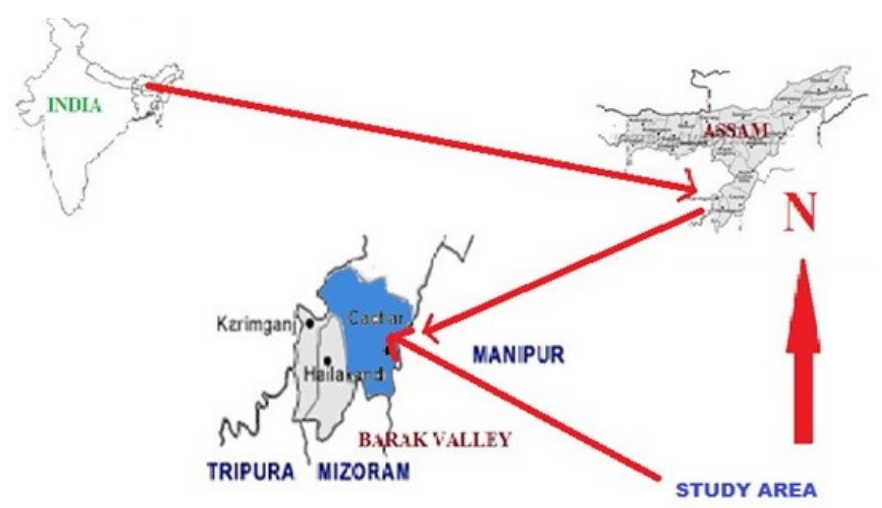

Figure 1. Location of the study area (Source: Google maps). 


\section{RESULTS AND DISCUSSION}

Temporal variation of crop yield: The temporal (yearly) variations of yield of various crops were collected and analyzed for the years 2007-2010 and 2011-2012. Table 2 shows the descriptive analysis of the available crop yield data of Cachar district (2007-2010 and 2011-2012) for twentythree major crops grown in this region. Out of the various cereals, Summer/Sali Paddy has the highest mean value of production $(186226.5$ tonne; 1 tonne $=1000 \mathrm{~kg})$, followed by Autumn/Ahu Paddy (15131.5 tonne) which concurs with the fact that rice is the staple food of the region and hence grown in abundance. Among the different pulses Black Gram has the highest mean yield (497.75 tonne) and Lentil the lowest (12.25 tonne). Rape and Mustard have the highest mean yield of 1222.75 tonne and Niger the lowest (7.75 tonne) among the oilseeds. Cachar district with its unique climatological features and soil is highly conducive to Jute cultivation and among the fibrous crops Jute has the highest mean yield of 548.5 bales $(1 \mathrm{bale}=170 \mathrm{~kg})$, while Cotton and Mesta have 37.5 bales and 30.5 bales, respectively. Potato is also widely grown in the region with a mean yield of 12434.5 tonne. Kharif and Rabi vegetables have a mean yield of 51767.25 tonne and 103876.8 tonne, respectively. For the years under consideration Rabi Vegetables has the highest deviation (29908.0), as its yield has increased with time and the lowest deviation was observed for Green gram (0.81). This suggests that the dispersion characteristics of crop yield in Cachar district can range from very high to low. The coefficient of variation $(\mathrm{Cv})$ which indicates the relative deviation among the various crops is highest for Mesta (31.73\%) and lowest for Sesamum (2.44\%). This heterogeneity of $C v$ in the crop yield produced in the study years can be attributed to various factors, climate change being foremost of them. Ajadi et al. (2011) observed the changes in climatic parameters such as solar radiation, temperature; moisture, rainfall etc.

Temporal variation of climatic parameters: Table 3 shows that for $A h u$ Paddy with crop growth season February-July, highest rainfall occurred in 2009-2010 (1499.4 mm) and the highest total hours of sunshine was recorded in 2007-2008 (1057.1). For Boro Paddy (June-December), highest rainfall occurred in 2008-2009 (2064.9 $\mathrm{mm})$ and highest sunshine hours (1181.3) recorded in 2007-2008. Sali Paddy, which has crop growth season of November-June, experienced highest rainfall of $1516.3 \mathrm{~mm}$ in 2009-2010 and highest sunshine hours of 1487 in 2007-2008. Kharif season (April-September) always experiences the highest amount of rainfall among all the seasons, the peak value being $2095.7 \mathrm{~mm}$ in 2007-2008 whereas Rabi season (October-March) recorded the lowest rainfall of $203.3 \mathrm{~mm}$ in 2011-2012. In all the years under consideration, the average maximum and minimum temperature for the various crop growth seasons did not display much fluctuation. The descriptive pattern of the various climatic data, indicate that some of the climatic parameters vary from one year to another and hence the variation in crop yield.

Table 1. The details of the crop and crop growth season of the study area.

\begin{tabular}{|c|c|c|}
\hline Crop & Botanical name & Crop growth season \\
\hline Ahu/Autumn Paddy & & February-July \\
\hline Sali/Winter Paddy & Oryza sativa & June-December \\
\hline Boro/Summer Paddy & & November-June \\
\hline Green Gram & Vigna radiate & \\
\hline Arahar & Cajanus cajan & \\
\hline Black gram & Vigna mungo & \\
\hline Ground Nut & Arachis hypogaea & \\
\hline Jute & Corchorus oliotorus & \\
\hline Maize & Zea mays & April- September \\
\hline Sesamum & Sesamum indicum & \\
\hline Mesta & Hibiscus cannabinus & \\
\hline Cotton & Gossypium arboretum & \\
\hline Millet & Pennisetum glaucum & \\
\hline Kharif vegetables & - & \\
\hline Wheat & Triticum aestivum & \\
\hline Lentil & Lens culinaris & \\
\hline Pea & Pisum sativum & \\
\hline Gram & Cicer arietinum & \\
\hline Rape & Brassica napus & \\
\hline Mustard & Brassica juncea & October-March \\
\hline Linseed & Linum usitatissimum & \\
\hline Niger & Guizotia abyssinica & \\
\hline Potato & Solanum tuberosum & \\
\hline Rabi vegetables & - & \\
\hline
\end{tabular}


Table 2. Descriptive statistics of the crop yield data.

Crop yield (Cotton, Jute, Mesta in bales*, others in tonne ${ }^{* *}$ )

\begin{tabular}{|c|c|c|c|c|c|c|c|}
\hline Crop & 2007-2008 & 2008-2009 & 2009-2010 & 2011-2012 & Mean yield & $\sigma$ & $C v(\%)$ \\
\hline Ahu Paddy (Feb-July) & 15701 & 13808 & 16457 & 14560 & 15131.5 & 1177.50 & 7.78 \\
\hline Sali Paddy (June-Dec) & 157287 & 199711 & 204084 & 183824 & 186226.5 & 21165.9 & 11.37 \\
\hline Boro Paddy (Nov-June) & 18941 & 21126 & 16448 & 13645 & 17540 & 3224.16 & 18.38 \\
\hline \multicolumn{8}{|c|}{ Kharif crops ( April-September) } \\
\hline Millets & 13 & 14 & 15 & 14 & 14 & 0.82 & 5.83 \\
\hline Green Gram & 16 & 17 & 18 & 17 & 17 & 0.81 & 4.8 \\
\hline Arahar & 91 & 86 & 87 & 82 & 86.5 & 3.7 & 4.27 \\
\hline Black Gram & 489 & 521 & 518 & 463 & 497.75 & 27.29 & 5.48 \\
\hline Ground-nut & 13 & 17 & 16 & 15 & 15.25 & 1.71 & 11.19 \\
\hline Jute & 409 & 571 & 579 & 635 & 548.5 & 97.26 & 17.73 \\
\hline Sesamum & 100 & 97 & 95 & 95 & 96.75 & 2.36 & 2.44 \\
\hline Maize & 53 & 50 & 50 & 59 & 53 & 4.24 & 8.00 \\
\hline Mesta & 44 & 23 & 31 & 24 & 30.5 & 9.68 & 31.73 \\
\hline Cotton & 42 & 35 & 34 & 39 & 37.5 & 3.7 & 9.86 \\
\hline Kharif Vegetables & 46945 & 50236 & 50343 & 59545 & 51767.25 & 5419.74 & 10.46 \\
\hline \multicolumn{8}{|c|}{ Rabi crops (October-March) } \\
\hline Wheat & 164 & 128 & 168 & 169 & 157.25 & 19.62 & 12.48 \\
\hline Lentil & 13 & 11 & 12 & 12.768 & 12.25 & 0.96 & 7.81 \\
\hline Chickpea & 28 & 28 & 28 & 32 & 29 & 2 & 6.89 \\
\hline Pea & 241 & 224 & 250 & 216 & 232.75 & 15.52 & 6.67 \\
\hline Linseed & 12 & 14 & 14 & 12 & 13 & 1.15 & 8.88 \\
\hline Niger & 7 & 7 & 9 & 8 & 7.75 & 0.96 & 12.35 \\
\hline Rape and Mustard & 1210 & 1341 & 1297 & 1042 & 1222.5 & 132.07 & 10.80 \\
\hline Potato & 8679 & 12082 & 15290 & 13687 & 12434.5 & 2825.52 & 22.72 \\
\hline Rabi Vegetables & 86324 & 90354 & 90177 & 148652 & 103876.8 & 29908.0 & 28.79 \\
\hline
\end{tabular}

$* * 1$ bale $=170 \mathrm{~kg} ; * 1$ tonne $=1000 \mathrm{~kg}$

Table 3. Pattern of agro-climatic data considered to study the impact on crop yield.

\begin{tabular}{|c|c|c|c|c|c|}
\hline Duration/ Crop growth season & Year & $\begin{array}{c}\text { Total rainfall, } \\
\text { mm }\end{array}$ & $\begin{array}{l}\text { Average maximum } \\
\text { temperature, }{ }^{\circ} \mathrm{C}\end{array}$ & $\begin{array}{l}\text { Average minimum } \\
\text { temperature, }{ }^{\circ} \mathrm{C}\end{array}$ & $\begin{array}{l}\text { Hours of } \\
\text { sunshine }\end{array}$ \\
\hline \multirow{4}{*}{$\begin{array}{l}\text { Season of } A h u \text { Paddy } \\
\text { (Feb - July) }\end{array}$} & $2007-2008$ & 1419.3 & 30.91 & 20.70 & 1057.1 \\
\hline & $2008-2009$ & 1347.1 & 31.34 & 21.00 & 989.9 \\
\hline & $2009-2010$ & 1499.4 & 32.8 & 20.98 & 993.9 \\
\hline & $2011-2012$ & 1346.2 & 32.60 & 23.46 & 844.8 \\
\hline \multirow[t]{2}{*}{ Mean } & - & 1403.0 & 31.91 & 21.54 & 971.43 \\
\hline & $2007-2008$ & 1824.3 & 30.94 & 22.22 & 1181.3 \\
\hline \multirow{3}{*}{$\begin{array}{l}\text { Season of Sali Paddy } \\
\text { (June-Dec) }\end{array}$} & $2008-2009$ & 2064.9 & 31.44 & 22.10 & 1146.2 \\
\hline & $2009-2010$ & 1761.8 & 31.82 & 22.31 & 1161.1 \\
\hline & 2011-2012 & 1433.4 & 31.83 & 21.86 & 1108.2 \\
\hline \multirow[t]{2}{*}{ Mean } & - & 1771.1 & 31.51 & 22.12 & 1149.2 \\
\hline & $2007-2008$ & 1047.3 & 29.38 & 18.27 & 1487 \\
\hline \multirow{3}{*}{$\begin{array}{l}\text { Season of Boro Paddy } \\
\text { (Nov-June) }\end{array}$} & 2008-2009 & 933.1 & 30.76 & 18.09 & 1467.5 \\
\hline & $2009-2010$ & 1516.3 & 29.72 & 17.81 & 1254.8 \\
\hline & $2011-2012$ & 1307.3 & 29.62 & 17.37 & 1330.3 \\
\hline \multirow[t]{3}{*}{ Mean } & - & 1463.1 & 30.58 & 19.33 & 1247.78 \\
\hline & $2007-2008$ & 2095.7 & 32.21 & 24.06 & 938.5 \\
\hline & 2008-2009 & 2135.8 & 32.92 & 24.05 & 936.2 \\
\hline \multirow{2}{*}{$\begin{array}{l}\text { Kharif season } \\
\text { (April-Sept) }\end{array}$} & $2009-2010$ & 1936 & 33.37 & 24.15 & 966.3 \\
\hline & $2011-2012$ & 1906.1 & 32.91 & 24.02 & 775.2 \\
\hline \multirow[t]{2}{*}{ Mean } & - & 1644.83 & 31.77 & 22.17 & 950.03 \\
\hline & $2007-2008$ & 601.4 & 27.88 & 16.46 & 1122.4 \\
\hline \multirow{3}{*}{$\begin{array}{l}\text { Rabi season } \\
\text { (Oct-March) }\end{array}$} & 2008-2009 & 284.4 & 29.74 & 16.46 & 1135.4 \\
\hline & $2009-2010$ & 289.6 & 29.52 & 16.34 & 1091.2 \\
\hline & $2011-2012$ & 203.3 & 29.52 & 16.34 & 1112 \\
\hline Mean & - & 245.15 & 29.58 & 16.37 & 1112.65 \\
\hline
\end{tabular}


Table 4. Coefficient of correlation $(r)$ between crop yield (tonne/bale) and climatic parameters for the various selected crops.

\begin{tabular}{|c|c|c|c|c|c|}
\hline & Names of crops & $\begin{array}{c}\text { Total rainfall, } \\
\mathbf{m m}\end{array}$ & $\begin{array}{c}\text { Average maximum } \\
\text { temperature, }{ }^{\circ} \mathrm{C}\end{array}$ & $\begin{array}{c}\text { Average minimum } \\
\text { temperature, }{ }^{\circ} \mathrm{C}\end{array}$ & Hours of sunshine \\
\hline \multirow{4}{*}{ Paddy } & $A h u$ & 0.95 & 0.30 & -0.35 & 0.40 \\
\hline & Sali & 0.19 & 0.76 & 0.07 & -0.34 \\
\hline & Boro & -0.76 & 0.62 & 0.89 & 0.74 \\
\hline & Millets & -0.57 & 0.99 & 0.66 & 0.13 \\
\hline \multirow{14}{*}{ Kharif crops } & Sesamum & 0.78 & -0.88 & -0.19 & 0.43 \\
\hline & Maize & -0.52 & -0.26 & -0.68 & -0.95 \\
\hline & Green Gram & -0.57 & 0.99 & 0.66 & 0.13 \\
\hline & Arahar & 0.61 & -0.51 & 0.40 & 0.82 \\
\hline & Black Gram & 0.46 & 0.40 & 0.65 & 0.87 \\
\hline & Groundnut & 0.02 & 0.79 & 0.21 & 0.13 \\
\hline & Jute & -0.61 & 0.80 & -0.06 & -0.53 \\
\hline & Mesta & 0.26 & -0.67 & 0.23 & 0.43 \\
\hline & Cotton & 0.14 & -0.90 & -0.56 & -0.35 \\
\hline & Kharif Vegetables & -0.70 & 0.35 & -0.47 & -0.92 \\
\hline & Wheat & 0.12 & -0.34 & -0.66 & -0.76 \\
\hline & Lentil & 0.44 & -0.68 & -0.25 & -0.31 \\
\hline & Chickpea & -0.54 & 0.27 & -0.58 & -0.12 \\
\hline & Pea & 0.50 & -0.38 & -0.01 & -0.54 \\
\hline \multirow{5}{*}{ Rabi crops } & Linseed & -0.19 & 0.46 & 0.14 & -0.07 \\
\hline & Niger & -0.38 & 0.37 & -0.78 & -0.94 \\
\hline & Rape and Mustard & 0.16 & 0.14 & 0.46 & 0.15 \\
\hline & Potato & -0.86 & 0.83 & -0.84 & -0.67 \\
\hline & Rabi Vegetables & -0.59 & 0.33 & -0.60 & -0.13 \\
\hline
\end{tabular}

Impact of climatic parameters on crop yield: Statistical techniques were employed in the agro-climatic variation analysis of both crop yield data and climatic parameters because of their vital roles in revealing the relationship and variation among variables. The correlation coefficients $(r)$ between any of the climatic parameters such as rainfall, maximum and minimum temperature, sunshine hours and the yield of any particular crop were computed by Pearson's product moment (Eq. 4) considering the climatic data for that particular growing season of that particular crop. The values of $r$ between 0.7 and $1.0(-0.7$ and -1.0$)$ indicated a strong positive (negative) linear relationship, as had been mentioned earlier. The values of $r$ for the twenty-three crops and the climatic parameters have been summarized in a nutshell in Table 4.

Rainfall was found to have a strong positive correlation with Ahu Paddy ( $r=0.95)$, Sesamum $(r=0.78)$, Arahar $(r=0.61)$ implying that as rainfall increased, the yields of the aforementioned crops also increased, and bore a strong negative correlation with Boro Paddy $(r=-0.76)$, Jute $(r=-0.61)$, Potato $(r$ $=-0.86)$ and Kharif vegetables $(r=-0.70)$. Hours of sunshine was found to have strong positive correlation with Boro Paddy $(r=0.74)$, Arahar $(r=0.82)$, Black Gram $(r=0.87)$ and strong negative correlation with Maize $(r=-0.95)$, Kharif vegetables $(r=-0.92)$, Niger $(r=-0.94)$ and Wheat $(r=$ 0.76). Barring Lentil ( $r=-0.68)$ and Potato $(r=0.83)$, average maximum temperature did not have any strong correlation with any of the other Rabi crops. On the other hand, average maximum temperature had strong positive correlation with Sali Paddy $(r=0.76)$, Millet and Green Gram $(r=0.99$ for both), Groundnut $(r=0.79)$, Jute $(r=0.80)$ and strong negative correlation with Sesamum $(r=-0.88)$ as well as cotton $(r$ $=-0.90)$. Strong negative correlation was observed for average minimum temperature with Niger $(r=-0.78)$, Potato $(r=$ $0.84)$ and a positive correlation with Boro Paddy $(r=0.89)$. The results are in agreement with Mishra et al. (2013) who reported the spatial variation in different climate variables and their impacts on the yield of rice and wheat in the Indian Ganga Basin.

Among the four considered climatic parameters, rainfall was found to have most effects due to its fluctuations on the yield of various crops. During the year 2008-2009 and 2011-2012, 3.98 and $4.04 \%$ decrease of rainfall $(1347.1 \mathrm{~mm}$ and 1346.2 mm, respectively) during the crop growth season of $A h u$ Paddy resulted in 8.75 and $3.78 \%$ decrease of crop yield (13808 tonne and 14560 tonne). This justifies the strong positive correlation ( $r=0.95)$ between Ahu Paddy and rainfall during that particular crop growth season. Boro Paddy which bears a strong negative correlation $(r=-0.76)$ with rainfall exhibited $20.44 \%$ increase in crop yield (21126 tonne) during the year $2008-2009$ due to $19.07 \%$ decrease of rainfall $(1433.4 \mathrm{~mm})$. Also, a drastic $145.32 \%$ increase of rainfall $(601.4 \mathrm{~mm})$ from the mean value of $245.15 \mathrm{~mm}$ during Rabi season of 20072008, resulted in 22.96 and $16.89 \%$ decrease in yield of Potato $(r=-0.86)$ and Rabi vegetables $(r=-0.59)$, respectively during that year. Thus, analysis of the values of coefficient of correlation with strong positive/negative association with various crops suggest, perceptible variation in crop yield could be attributed to climatic changes and comparatively an insig- 
nificant part pertaining to non-climatic factors like soil fertility and farm techniques of the study region. Chavas et al. (2009) reported the long term impact of climate change on agricultural productivity of different agricultural crops in eastern China. Gohari et al. (2013) also reported the changes in the crop yield of various crops in Iran's Zayandeh-Rud River Basin.

\section{Conclusions}

The results obtained from correlation analysis reveal that though there has been increase in the area of cultivation of crops and provision of farm inputs to farmer, however climate has taken its toll on the selected crops. Taking into consideration the array of factors mitigating crops' yield in Cachar district, Assam, climate has been identified as the major perpetrator that is impossible to control in the open field. This analysis of climate change and its impact on crop yield can help to deal with the repercussions and the crop production changes can be specified in different conducive regions, thus strengthening the sustainability of agricultural production. As a result, this study recommends the following measures towards improving crop production and agriculture in the study area: Rainwater harvesting in top and foothills of hilly areas along with integrated water resources management (IWRM) and crop planning. And vulnerability and adaptation assessments of climate change to prioritize adaptation policies and measures and these adaptations should be mainstreamed in developmental planning.

\section{ACKNOWLEDGEMENTS}

The authors are grateful to Tea Research Association, Silcoorie, Cachar district and Department of Agriculture, Cachar district for providing us with the necessary data to conduct this research work.

Open Access: This is open access article distributed under the terms of the Creative Commons Attribution License, which permits unrestricted use, distribution, and reproduction in any medium, provided the original author(s) and the source are credited.

\section{REFERENCES}

Ajadi, B.S., Adedapo, A. and Tunde, A.M. (2011). Impact of climate on urban agriculture: Case study of Ilorin City, Nigeria. Global Journal of Human Social Science Research, 11(1): 25-29.

Anonymous (2012-2013). Status Paper of Department of Agriculture, Cachar district, Assam.

Chavas, D.R., Izaurralde, R.C., Thomson, A.M. and Gao, X. (2009). Longterm climate change impacts on agricultural productivity in eastern China. Agricultural and Forest Meteorology, 149(6): 1118-1128.

Gohari, A., Eslamian, S., Abedi-Koupaei, J., Bavani, A.M., Wang, D. and Madani, K. (2013). Climate change impacts on crop production in Iran's Zayandeh-Rud River Basin. Science of the Total Environment, 442: 405-419.

IPCC. (2007). Climate Change 2007: The physical science basis. Contribution of Working Group I to the Fourth Assessment Report of the Intergovernmental Panel on Climate Change. Cambridge, United Kingdom and New York, NY, USA.

Kumar, V. and Chopra, A.K. (2009). Impact of climate change on biodiversity of India with special reference to Himalayan region-An Overview. Journal of Applied and Natural Science, 1(1): 117-122.

Kumar, V., Dhaliwal, R.K. and Kaur, M. (2015). Scientists' perception regarding effect of climate change on agriculture. Indian Journal of Soil Conservation, 43(2): 192-196.

Manna, M.C., Rao, A.S. and Mandal, A. (2015). Impact of agricultural land management practices on soil carbon sequestration. Indian Journal of Soil Conservation, 43(3): 204-212.

Mishra, A., Singh, R., Raghuwanshi, N.S., Chatterjee, C. and Froebrich, J. (2013). Spatial variability of climate change impacts on yield of rice and wheat in the Indian Ganga Basin. Science of the Total Environment, 468: S132-S138.

Mitchell, J.M.Jr., Dzerdzeevskii, B., Flohn, H., Hofmeyr, W.L., Lamb, H.H., Rao, K.N. and Wallén, C.C. (1966). Climatic Change. WMO Technical Note No 79, World Meteorological Organization, Geneva, 79.

Olaniran, O.J. (1981). Research in agroclimatology in Nigeria. Journal of Agricultural Research, 19(1): 15-29.

Olarenwaju, R.M. (2012). Effect of climate on yam production in Kwara State, Nigeria. Environ. Issues, Department of Geography and Environmental Management, University of Ilorin, Ilorin, 3(1).

Ruane, A.C., Major, D.C., Winston, H.Y., Alam, M., Hussain, S.G., Khan, A.S., Hassan, A., Al Hossain, B.M.T., Goldberg, R., Horton, R.M. and Rosenzweig, C. (2013). Multi-factor impact analysis of agricultural production in Bangladesh with climate change. Global Environment Change, 23(1): 338-350. 